This article is (c) Emerald Group Publishing and permission has been granted for this version to appear here (https://dspace.lib.cranfield.ac.uk/index.jsp). Emerald does not grant permission for this article to be further copied/distributed or hosted elsewhere without the express permission from Emerald Group Publishing Limited. www.emeraldinsight.com

\title{
High Commitment Performance Management: The Roles of Justice and Trust
}

Elaine Farndale (Corresponding author)

Department of Human Resource Studies, Tilburg University, PO Box 90153, 5000 LE Tilburg, The Netherlands

\& Labor Studies \& Employment Relations, Pennsylvania State University, USA

Email: farndale@uvt.nl

Tel.: +31 (0)134662371

Dr Elaine Farndale is Assistant Professor in the Department of Human Resource Studies at Tilburg University in the Netherlands. She is a member of the Change Management Consortium Research team at Cass Business School, City University in the UK. Her specialist areas of interest include: international HRM; the power, professionalism and roles of the HR department; change management and HRM; and eHRM and new HR delivery mechanisms. Her work has been published in refereed academic journals and practitioner publications, as well as presented at international academic conferences.

\section{Veronica Hope-Hailey}

Cass Business School, 106 Bunhill Row, London EC1Y 8TZ, UK

Email: veronica.hope-hailey.1@,city.ac.uk

Tel: +44 (0)207 0408683

Veronica is Associate Dean of the MBA Programmes and Professor of HRM and Change at Cass Business School at City University in the City of London. She has also held Professorships at Cranfield School of Management and the University of Bath. Her research and teaching interests centre on issues of change at both a strategic and organisational level, and also at the level of individual managerial practice and personal development. Veronica is also the Director of the Change Management Consortium which conducts collaborative research with major private sector and public sector organizations. 


\title{
Clare Kelliher
}

Cranfield School of Management, Cranfield University, Cranfield, Bedford MK43 0AL, UK

Email: clare.kelliher@cranfield.ac.uk

Tel: $+44(0) 1234751122$

Dr Clare Kelliher is Reader in Work and Organisation Cranfield School of Management, Cranfield University. She is a member of the Change Management Consortium Research team at Cass Business School, City University. Clare's research interests centre on the organisation of work and the management of the employment relationship in the context of organisational change. She has particularly interests in the use and implementation of flexible working practices. She has authored many published papers and book chapters and regularly presents at national and international conferences.

\begin{abstract}
Purpose: This paper explores the relationship between employees' perceptions of a particular subsystem of HRM practices (performance management) and their commitment to the organization. In addition, the study examines the mechanisms by which these perceptions translate into employee attitudes and behaviours.
\end{abstract}

Methodology: 524 questionnaire responses were collected from four organizations in the UK. Findings: The findings show the link between employee experiences of high commitment performance management (HCPM) practices and their level of commitment is strongly mediated by related perceptions of organizational justice. In addition, the level of employee trust in the organization is a significant moderator.

Research limitations: This is a cross-sectional study based on self-report data which limits the reliability of the findings. The findings may also be specific to a particular context, however, the results by company support their generalisability.

Practical implications: The findings lead us to believe that it is essential to observe the actual experiences of HCPM practices and outcomes at employee level, and to consider the broader organizational context, if we are to understand their effects on performance.

Originality: When exploring the impact of high commitment work practices on firm performance, little attention has been paid to the employee perspective: employees ultimately are the recipients of an organization's HRM practices, and as such their perceptions of these practices affect their attitudes and behaviour in the workplace.

Keywords: performance management; organizational justice; trust; commitment; research paper 


\section{INTRODUCTION}

There has been intense interest within the HRM field regarding how HRM can add value to organizations, leading to an increasing focus on high performance work systems (HPWS) (Macky and Boxall, 2007). At the same time, commentators have increasingly argued the need to revise existing research to address some of the inherent methodological weaknesses in the field (Guest, 1997; Wood, 1999). One issue is that many models of HRM and firm performance are based on theoretical assumptions about the outcomes of certain HRM practices, rather than on empirical observation (Paauwe and Farndale, 2005: 97). Guest (1999) also argues for more attention to be paid to the employee perspective in this debate, alongside the more common organizational level variables.

Conceptual models have started to explore the links between HRM practices and HRM outcomes. HRM practices can take three different forms: intended, actual and perceived (Wright and Nishii, 2004). Intended HRM includes the policies and practices put together at organization level. These practices are then enacted by line management in the process of implementation, and may or may not be carried out as originally intended. The employee is ultimately the recipient of these practices, forming his or her own perceptions of them. These perceptions then influence employee-level outcomes by affecting the way the employee thinks, feels or behaves (Purcell et al., 2003). This debate is often referred to as 'opening the black box' between HRM and performance (Guest, 1997; Purcell et al., 2003).

One dimension of the HRM/performance debate focuses on the notion that practices can be designed to create a particular HRM outcome, in this case high commitment - so called high commitment work practices (HCWP). Commitment is seen as a fundamental requirement to achieve such desirable outcomes as higher job satisfaction and lower absenteeism (Mathieu and Zajac, 1990), higher organization citizenship behaviour and employees who are willing to 'go the extra mile' (Organ, 1990). We focus here on a sub-system of practices within HCWPs: high commitment performance management (HCPM). HCPM includes performance management practices which are designed to engender commitment from employees through involvement and personal development, such as regular appraisal feedback, input into the process of target setting, choosing pay and benefit options, and appraisals leading to development opportunities and new targets. HCPM is argued to affect an employee's perceptions of organizational actions, which leads to related employee attitudes and behaviours (Den Hartog et al., 2004). We need, however, to look deeper into how this process works. The approach adopted here is to consider how the extant organizational climate affects employee reactions using theories of organizational justice and trust.

We present the argument that for performance management practices to have the effect of achieving high commitment, this depends on the extent to which employees perceive these practices to be fair, both in terms of the process and the outcomes. Organizational justice is proposed to play a key mediating role in this relationship, and has been found to explain a wide range of employee behaviours (Greenberg, 1990).

In addition, the broader macro-environment of the organizational context creates the conditions under which the employee-employer relationship is formed (Den Hartog et al., 2004). This affects how employees perceive performance management practices and again influences the related behaviour and attitudes. Particularly, the extent of trust that employees have in the organization as represented by senior management is an important aspect of organizational climate (McAllister, 1995; Macky and Boxall, 2007). Trust, it is argued here, 
moderates the extent to which performance management practices can lead to perceptions of justice and employee commitment.

In summary, this study explores the effect of employee perceptions of the fairness of performance management practices on organizational commitment and the impact of trust in senior management on this relationship. The related issues of commitment, perceived distributive, procedural, and interactional justice and organizational trust are first discussed. A model of HCPM and its relationship with these variables is then constructed based on extant theory and tested in an empirical study to explore its applicability to theory and practice.

\section{HIGH COMMITMENT PERFORMANCE MANAGEMENT}

Employee commitment denotes a belief in and acceptance of the goals and values of an organization, a willingness to exert effort on behalf of the organization, and a strong desire to maintain membership of the organization (Mowday, et al. 1979). This HRM outcome has a strong relationship with organizational success factors such as higher job satisfaction, lower absenteeism and organization citizenship behaviour (e.g. Mathieu and Zajac, 1990; Organ, 1990). It has thus been argued that individuals with high levels of commitment are more willing to devote greater efforts towards an organization's goals and objectives (Guest, 1987). In order to support a desire for high commitment, certain HRM practices can therefore be put in place in organizations.

The term 'high commitment' is frequently used (incorrectly) interchangeably with terms like 'high involvement' and 'high performance', the former being more prominent in the UK and the latter two in the US literature (Gould-Williams, 2004). The tendency in the 'high performance' literature is to identify a set of HRM best practices which together will improve firm performance (Guest, 1987; Whitener, 2001; Wood \& de Menezes, 1998). However, the variety of practices included in these different studies has led to confusion over which HRM practices should be regarded as 'high performance'. More recently, Boxall and Macky (2009) have highlighted that high involvement and high commitment work practices are not synonymous: although high involvement work practices tend to engender high commitment, the reverse is not necessarily the case. For example, practices which enhance empowerment have been found to have a significant effect on employee commitment (Gardner et al., 2001). However, there are many studies which show that employee commitment can be achieved by routes other than those incorporating high involvement, such as pay and job security (Boxall \& Macky, 2009).

Like the 'high involvement' literature, the 'high commitment' literature focuses on desired outcomes more than on practices themselves (Wood \& de Menezes, 1998). In general, studies of high involvement or high commitment work practices have a clearer definition of the desired outcome (involvement or commitment) compared to the more generic high performance literature in which 'performance' can have many interpretations (Boxall \& Macky, 2009). High commitment HRM is about shaping employee behaviours and attitudes by developing psychological links between organizational and individual goals to increase effectiveness and productivity (Arthur, 1994). Correspondingly, the practices that represent a high commitment strategy include any sets of HRM policies and procedures that affect employee commitment (Whitener, 2001).

Focusing in particular on the performance management dimensions of HCWPs, these practices are recognized as increasingly central to high performing organizations. 
Performance management itself is "an integrated process in which managers work with their employees to set expectations, measure and review results, and reward performance, in order to improve employee performance, with the ultimate aim of positively affecting organizational success" (Den Hartog et al., 2004: 557). The primary aim is to provide guidance to employees on how to apply their resources for the benefit of the organization (Gardener et al., 2001). Performance management practices represent an important element in the HRM process and have particular significance for notions of high commitment (Fletcher and Williams, 1996), although as yet evidence of a direct linkage is weak (Guest et al., 2003).

We argue here that there are two types of commitment-enhancing performance management practices. The first, as noted above, has a high involvement focus and includes personal involvement in setting objectives, having frequent opportunities to discuss performance and receive feedback, and having some choice over the pay and benefits received. In return for these organizational practices, the employee reciprocates with higher commitment to the organization in line with social exchange theory (Blau, 1964). The second type focuses on employees feeling they have opportunities to develop, with the reciprocal repayment of this investment again in terms of commitment and a lower intention to leave. Such practices include appraisal discussions which result in training and development opportunities and new challenges being set for the employee to work towards. Combined, we refer to these practices further as High Commitment Performance Management (HCPM): a sub-system of practices within HCWPs focusing on the three dimensions of performance management (appraisal, target setting and reward).

These HCPM practices effectively represent an intersection of the organization's and individual's interests, and are fully facilitated by line managers and supervisors. Outcomes of these processes are generally explicit and consequently may provide a focus for employees' assessment of the organization. Equally, decisions about performance are in many organizations frequent, regular occurrences and so capturing employee perceptions in relation to them may be more realisable than for other HRM activities. Therefore, the first hypothesis is presented as follows:

H1: The more employees are the recipients of HCPM practices, the higher their level of commitment.

It has been suggested that there is a need to understand the broader organizational context in which performance management occurs to understand its outcomes (Den Hartog et al., 2004). Organizational context is explored here further in terms of the extant organizational climate, including employee perceptions of justice in HCPM practices, and their levels of organizational trust.

\section{THE ROLE OF ORGANIZATIONAL JUSTICE}

In studying the outcomes of HCPM, it is interesting to explore not only what practices are implemented, but also how they are experienced by employees (Gratton and Truss, 2003). Guest (1999) argues that the way in which employees perceive and evaluate HRM practices impacts employee behaviour and attitudes. Employee perceptions of performance management practices are thus of crucial importance (Purcell et al., 2003; Wright and Nishii, 2004), and can be explained with the help of organizational justice theories. Organizational justice can explain a wide range of employee behaviours and highlights the importance of the 
ideals of justice and fairness as a requirement for organizations to function effectively (Greenberg, 1990).

The two most prevalent forms of organizational justice discussed in the literature are distributive and procedural justice (Folger and Konovsky, 1989; Greenberg, 1990). Distributive justice refers to the perceived equity of outcomes for individuals, for example, whether the performance appraisal process results in what the individual perceives to be a fair evaluation. Procedural justice refers to the individual's perception of the fairness of the process carried out, for example, to reach a final performance grading. An employee is said to be more likely to find the outcomes of HRM practices fair, if the process of those practices is perceived to be equitable (Folger and Konovsky, 1989). A process which allows employee involvement is also often perceived as being more fair (Greenberg, 1990). For example, if an employee is able to input into the process of setting targets, he or she is more likely to perceive those targets as fair.

Extant research shows that perceptions of procedural justice in HRM are related in particular to measures such as trust in management, job satisfaction and employee commitment (Folger and Konovsky, 1989; McFarlin and Sweeney, 1992). Distributive justice on the other hand is more closely related to outcome satisfaction, such as fairness of levels of pay and performance evaluations (Folger and Konovsky, 1989; Greenberg, 1990). Procedural justice is therefore a stronger predictor of evaluations of an organization as an institution, whereas distributive justice relates more closely to specific personal outcomes (McFarlin and Sweeney, 1992).

There is some debate in the literature regarding the extent to which distributive and procedural justice can actually be measured independently. However, Greenberg (1990) presents an overview of studies which have identified measures of distributive and procedural justice which are statistically independent, and show that employees are intuitively aware of the distinction, supporting the idea that these are separate, though related measures of organizational justice.

There is also a third type of organizational justice: interactional justice. This is argued to be a subset of procedural justice (Cropanzano et al., 2002), and is described as the interpersonal aspects of procedural justice (Greenberg, 1990). Whereas procedural justice focuses on the fairness of procedures relating an employee to an organization, interactional justice focuses on the interpersonal treatment employees receive from their managers during these procedures (Chang, 2005).

Organizational justice can thus help explain employee attitudes and behaviour, triggering employee commitment in organizations (Folger and Konovsky, 1989; McFarlin and Sweeney, 1992; Organ, 1990; Purcell et al., 2003). This leads to the following hypotheses:

H2a: The more employees are the recipients of HCPM practices, the more positive their perceptions of the justice of these practices.

$H 2 b$ : More positive perceptions of the justice of HCPM practices are associated with higher levels of employee commitment.

As justice perceptions are expected to be strongly related to employee commitment ( $c f$. Greenberg, 1990), we also anticipate a mediating effect of justice between experiences of HCPM and commitment: 
H2c: Employee perceptions of the justice of HCPM practices will mediate the relationship between the experienced HCPM practices and employee commitment.

\section{ORGANIZATIONAL TRUST}

In addition to the mediating role of organizational justice in the relationship between performance management practices and commitment, extant literature also shows that trust creates conditions which affect employee responses to HRM practices, including commitment (McAllister, 1995; Macky and Boxall, 2007).

There are many definitions of trust, as well as multiple types of trust which have differing effects on organizational behaviour (McAllister, 1995). A common organizational definition describes trust as: "a psychological state comprising the intention to accept vulnerability based upon positive expectations of the intentions or behaviours of another" (Rousseau et al., 1998: 395). Trust can be looked at from both the micro (an employee's job and line manager) and the macro perspective (their employer/senior management) (Ayree, et al., 2002). In order to understand the broader organizational context in which HRM practices are carried out and how employee perceptions of justice are formed, it is important to consider this macroenvironment. Costigan et al. (1998) claim that employee trust in senior management is (ibid: 304): "based on the outcomes of organizational decisions made by these top managers and less on direct experience of their character, words and actions." Therefore employee trust in senior management is interpreted through the company's policies and practices, in this case performance management practices.

Like organizational justice, trust has also been shown to lead to higher levels of organizational commitment (McAllister, 1995). For example, negative feedback from a trusted manager is likely to be considered as accurate by an employee, and they will try to improve their performance. Yet an employee is likely to doubt the accuracy of negative feedback from a manager who is not trusted, and will not attempt to improve their performance (Dirks and Ferrin, 2001).

Trust is thus not only an end in itself: it facilitates the effects of other determinants on desired outcomes such as commitment, cooperation, acceptance of decisions and higher performance, but in this sense it remains an undeveloped area of research. Dirks and Ferrin (2001: 451) acknowledge that there is empirical evidence that trust has a main effect, but also develop a theoretical argument that trust "moderates the relationship between an interaction partner's action and the trustee's response by influencing one's interpretation of the action". Levels of employee trust in their employer/senior management can therefore be seen as impacting the link between employee experiences of HCPM practices, and their related behavioural and attitudinal outcomes in terms of commitment and perceptions of justice. This leads to the final hypotheses for empirical investigation:

H3a: Higher levels of trust in employer/senior management are associated with higher levels of employee commitment.

$H 3 b$ : Employee levels of trust in their employer/senior management will moderate the relationship between experienced HCPM practices and employee commitment.

H4a: Higher levels of trust in employer/senior management are associated with higher levels of perceived organizational justice. 
H4b: Employee levels of trust in their employer/senior management will moderate the relationship between experienced HCPM practices and organizational justice perceptions.

In summary, our exploration of the extant literature to identify the relationships between HCPM practices and employee commitment has considered both a direct and indirect relationship between input factors and outcomes. In order to explore these relationships further, we present these in a model in Figure 1.

\section{Figure 1: Research model}

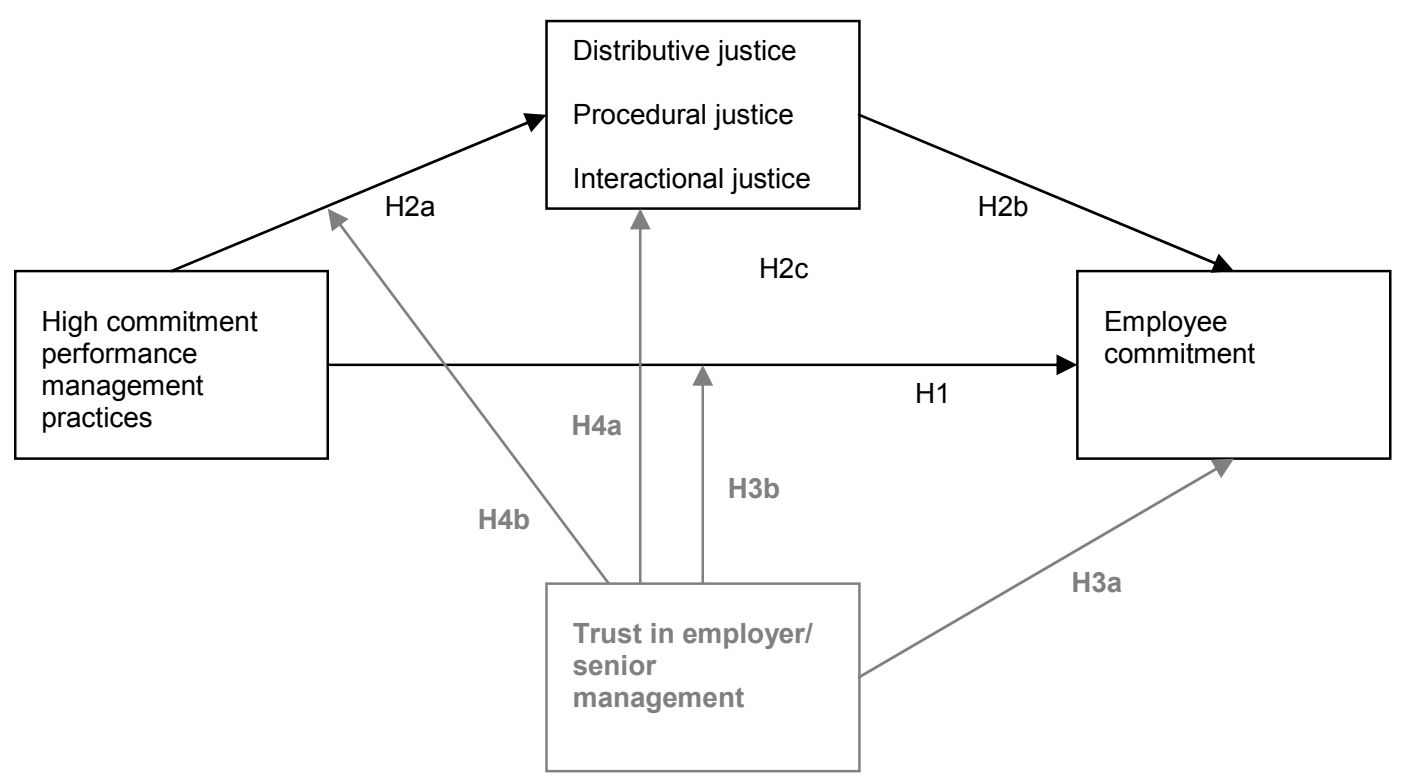

\section{METHODOLOGY}

To test the hypotheses, four large organizations in the UK were surveyed in 2004/5. For the purpose of corporate anonymity, the organizations are referred to here as Finance, Automotive, Foodstuff, and Communications, representing the sectors to which they belong. Questionnaires were distributed by internal post either to the full population of smaller business units, or a sample was selected by the organization based on selection of the $n^{\text {th }}$ employee on a non-stratified alphabetical listing (e.g. reducing a population of 800 to a sample of 200 participants). This was done in order to ensure in total a maximum of 200 respondents per organization to avoid over-dominance in the dataset of a single organization. Questionnaires were completed and returned anonymously direct to the researchers. The average response rate was $63 \%$. In total, 524 responses were received from the four organizations. The profile of respondents is presented in Table 1. Although Finance and Communication compose the larger share of the sample, the cases were not weighted in order to maintain the reliability of the original data. 
Table 1: Respondent profile

\begin{tabular}{ll}
\hline Organization $(\mathrm{n}=524)$ & $\%$ \\
\hline Finance & 37 \\
Automotive & 16 \\
Foodstuff & 16 \\
Communication & 31 \\
\hline Grade $(\mathrm{n}=519)$ & \\
\hline Senior management & 9 \\
Management & 34 \\
Professional & 16 \\
Administrative & 41 \\
\hline Gender $(\mathrm{n}=521)$ & \\
\hline Male & 47 \\
Female & 53 \\
\hline Age $(\mathrm{n}=523)$ & \\
\hline Under 20 & 1 \\
20-29 & 23 \\
30-39 & 29 \\
$40-49$ & 25 \\
50 or over & 23 \\
\hline Tenure $(\mathrm{n}=524)$ & \\
\hline Less than 5 years & 33 \\
6-15 years & 32 \\
$16-25$ years & 20 \\
More than 25 years & 14 \\
\hline
\end{tabular}

\section{Measures}

Firstly, six items were included regarding the HCPM practices as experienced by employees, including: appraisal frequency, outcomes of appraisal (training opportunities, targets), extent of personal involvement in target setting, and personal choice over pay and benefits. For the remaining variables, new scales were developed based on existing work and were all measured using a 5-point Likert scale (ranging from strongly disagree to strongly agree). An alpha factor analysis resulted in 7 factors covering justice, trust and commitment, which together account for $61 \%$ of variance:

- Distributive justice was measured using eight items, including validated items from the Price and Mueller (1986) Distributive Justice Index: 'fair considering effort' and 'fair considering responsibilities'. Two dimensions of distributive justice emerged in the factor analysis: distributive justice in appraisal and objective setting (Cronbach $\alpha=.89$ ) and distributive justice in reward practices (Cronbach $\alpha=.84$ ).

- The procedural justice measure, which included 9 items, was based on Folger and Konovsky (1989), but adapted specifically for questions regarding performance management. The Cronbach $\alpha$ for this scale was .91. (Note: Three items, those pertaining to procedural justice in reward practices, loaded highly (and with similar values) onto two factors: interactional justice in reward, and procedural justice in appraisal and objective setting. It was decided to group these three items with the other procedural justice items for the purpose of clarity in the results.)

- Interactional justice considered whether the employee feels he/she has been treated with dignity, sensitivity and consideration, and the quality of information used to reach decisions on performance, drawing upon the work by Bies and Moag (1986) and Skarlicki et al. (1999). In the factor analysis, two separate dimensions of interactional justice 
emerged from the six item scale: interactional justice in appraisal and objective setting (Cronbach $\alpha=.93$ ) and interactional justice in reward practices (Cronbach $\alpha=.93$ );

- Based on work by Cook and Wall (1980) and Gabarro \& Athos (1976), the measure for trust in employer/senior management asked for employee perceptions of the sincerity, equity and integrity of senior management. Eight items were included. The trust in employer/senior management scale had a Cronbach $\alpha$ of .90 .

- Employee commitment was measured using seven items from the 15-item Organizational Commitment Questionnaire (Mowday, et al., 1979). The scale was found to be reliable (Cronbach $\alpha=.83$ ).

The data was controlled for the impact of structural and demographic variables: organization, age, tenure, and job grade. Although significant differences were found in a number of variables based on these divisions, the data has not been weighted as within the organizations the respondents were found to be representative of the populations. However, it is acknowledged that such demographic variables do account for some of the variance in the outcomes measured (see, for example: McFarlin and Sweeney, 1992). Age was measured based on five groups in ten year intervals from under 20 to over 50 . Tenure was based on four groups in five year intervals from under 5 to over 25 years of service. Job grading was worded specifically for each company so that it would be meaningful to the respondent. With the help of an HR representative in each company, these specific job grades were mapped onto five general levels of job grade for comparability purposes (ranging from manual worker to senior management).

Table 2 shows the descriptive statistics for all variables. A number of correlations between variables are significant, with the highest being between procedural justice in performance management and interactional justice in appraisal and objective setting (.649). This might be expected given the theoretical discussion of the interrelatedness of these two concepts. Equally, there is a high correlation (.639) between age and length of service, which again might be expected. However, none of the correlations exceed .700: this, along with the prior research discussed above, indicates that the factors are sufficiently different measures of separate variables. Harman's single factor test was performed to test for the presence of common method variance bias (Podsakoff \& Organ, 1986). All variables were entered into a principal components analysis with varimax rotation. The results of the analysis indicated eight factors with eigenvalues greater than one, and no single factor accounted for more than $33.1 \%$ of the covariation. The results indicate that common method variance is not expected to affect the results. 
Table 2: Mean, standard deviation, Spearman correlations and reliability

\begin{tabular}{|c|c|c|c|c|c|c|c|c|c|c|c|c|c|c|c|c|c|}
\hline & $M$ & $S D$ & 1 & 2 & 3 & 4 & 5 & 6 & 7 & 8 & 9 & 10 & 11 & 12 & 13 & 14 & 15 \\
\hline 1. Grade ${ }^{a}$ & 2.89 & 1.04 & - & & & & & & & & & & & & & & \\
\hline 2. Age $^{\mathrm{b}}$ & 3.45 & 1.11 & $-.455^{* *}$ & - & & & & & & & & & & & & & \\
\hline 3. Tenure ${ }^{c}$ & 2.16 & 1.05 & $-.537^{* *}$ & $.639^{* *}$ & - & & & & & & & & & & & & \\
\hline 4. Frequency of appraisal ${ }^{\mathrm{d}}$ & 3.45 & 1.08 & .078 & $-.201^{* *}$ & $-.125^{* *}$ & - & & & & & & & & & & & \\
\hline $\begin{array}{l}\text { 5. Involvement in setting } \\
\text { objectives }^{\text {e }}\end{array}$ & 3.56 & 0.92 & $-.306^{* *}$ & $.157^{* *}$ & $.184^{* *}$ & -.028 & - & & & & & & & & & & \\
\hline $\begin{array}{l}\text { 6. Personal targets set in } \\
\text { appraisal }^{\mathrm{f}}\end{array}$ & 0.73 & 0.44 & $.139^{* *}$ & $-.190^{* *}$ & $-.165^{* *}$ & $.322^{* *}$ & -.002 & - & & & & & & & & & \\
\hline $\begin{array}{l}\text { 7. Training opportunities } \\
\text { offered in appraisal }^{\mathrm{f}}\end{array}$ & 0.55 & 0.50 & -.027 & -.040 & -.076 & $.190^{* *}$ & .031 & $.304^{* *}$ & - & & & & & & & & \\
\hline 8. Choice over pay ${ }^{\mathrm{f}}$ & 0.12 & 0.33 & -.073 & -.045 & -.079 & .046 & .035 & $.126^{* *}$ & .046 & - & & & & & & & \\
\hline $\begin{array}{l}\text { 9. Interactional justice in } \\
\text { appraisal/objective setting }\end{array}$ & 3.69 & 0.62 & $-.117^{* *}$ & -.015 & .011 & $.173^{* *}$ & $.159^{* *}$ & $.264^{* *}$ & $.305^{* *}$ & $.087^{*}$ & .928 & & & & & & \\
\hline $\begin{array}{l}\text { 10. Interactional justice in } \\
\text { reward }\end{array}$ & 3.28 & 0.79 & $-.352^{* *}$ & $.213^{* *}$ & $.164^{* *}$ & .020 & $.165^{* *}$ & .005 & $.183^{* *}$ & $.127^{* *}$ & $.495^{* *}$ & .926 & & & & & \\
\hline $\begin{array}{l}\text { 11. Procedural justice in } \\
\text { performance management }\end{array}$ & 3.32 & 0.68 & $-.188^{* *}$ & .010 & .047 & $.179^{* *}$ & $.159^{* *}$ & $.219^{* *}$ & $.315^{* *}$ & $.132^{* *}$ & $.649^{* *}$ & $.581^{* *}$ & .909 & & & & \\
\hline $\begin{array}{l}\text { 12. Distributive justice in } \\
\text { appraisal/objective setting }\end{array}$ & 3.37 & 0.84 & $-.092^{*}$ & $-.105^{*}$ & $-.113^{* *}$ & $.155^{* *}$ & $.154^{* *}$ & $.258^{* *}$ & $.253^{* *}$ & $.134^{* *}$ & $.469^{* *}$ & $.318^{* *}$ & $.481^{* *}$ & .888 & & & \\
\hline $\begin{array}{l}\text { 13. Distributive justice in } \\
\text { reward }\end{array}$ & 2.77 & 0.90 & $-.193^{* *}$ & $.125^{* *}$ & $.101^{*}$ & -.013 & .070 & .046 & $.141^{* *}$ & $.135^{* *}$ & $.267^{* *}$ & $.263^{* *}$ & $.320^{* *}$ & $.390^{* *}$ & .836 & & \\
\hline 14. Trust in employer & 3.21 & 0.68 & $-.128^{* *}$ & .032 & $-.093^{*}$ & .021 & $.126^{* *}$ & $.163^{* *}$ & $.189^{* *}$ & $.173^{* *}$ & $.389^{* *}$ & $.292^{* *}$ & $.383^{* *}$ & $.422^{* *}$ & $.367^{* *}$ & .899 & \\
\hline 15. Employee commitment & 3.50 & 0.67 & $-.103^{*}$ & $.150^{* *}$ & .011 & $-.091^{*}$ & $.091^{*}$ & $.097^{*}$ & $.182^{* *}$ & $.141^{* *}$ & $.285^{* *}$ & $.187^{* *}$ & $.243^{* *}$ & $.327^{* *}$ & $.325^{* *}$ & $.591^{* *}$ & .830 \\
\hline
\end{tabular}

$\mathrm{n}=524$

$* \mathrm{p}<.05, * * \mathrm{p}<0.01, * * * \mathrm{p}<0.001$

a $1=$ senior management, $2=$ management, $3=$ professional, $4=$ administrative

b $1=<20$ years, $2=20-29,3=30-39,4=40-49,5==>50$ years

c $1=<5$ years, $2=6$ to 15 years, $3=16-25$ years, $4=>25$ years

${ }^{\mathrm{d}} 1=$ never, $2=<1 \mathrm{p} / \mathrm{a}, 3=1 \mathrm{p} / \mathrm{a}, 4=2 \mathrm{p} / \mathrm{a}, 5=3 \mathrm{p} / \mathrm{a}, 6=4 \mathrm{p} / \mathrm{a}, 7=>4 \mathrm{p} / \mathrm{a}$

e $1=$ not aware of targets, $2=$ manager only, $3=$ manager with me, $4=$ me with manager, $5=$ me only

${ }^{\mathrm{f}} 1=$ yes, $0=$ no 


\section{RESULTS}

Firstly, the relationship between experienced HCPM practices and employee commitment was explored, followed by the inclusion of the hypothesized mediating variable, organizational justice (see Table 3). Summated scales for the organization justice factors were constructed using mean values. Tests included control variables, which in all cases were entered first into the equation, followed, as appropriate, by the other independent variables. It is noteworthy that organization is frequently a significant variable. This is likely due to the fact that the reference organization selected is Communications, the only public sector organization included in the sample. This point is discussed further below. 


\section{Table 3: Multiple regression results}

\begin{tabular}{|c|c|c|c|c|c|c|c|}
\hline \multirow[t]{2}{*}{ Independent variables } & \multicolumn{7}{|c|}{ Dependent variable: (Standardized $\beta$ ) } \\
\hline & $\begin{array}{c}\text { Employee } \\
\text { commitment }\end{array}$ & $\begin{array}{c}\text { Employee } \\
\text { commitment } \\
\text { H } 1\end{array}$ & $\begin{array}{c}\text { Employee } \\
\text { commitment } \\
\text { H } 1\end{array}$ & $\begin{array}{c}\text { Organization } \\
\text { al justice } \\
\text { H } 2 a\end{array}$ & $\begin{array}{c}\text { Organization } \\
\text { al justice } \\
\text { H } 2 a\end{array}$ & $\begin{array}{c}\text { Employee } \\
\text { commitment } \\
\text { H } 2 b\end{array}$ & $\begin{array}{c}\text { Employee } \\
\text { commitment } \\
\text { H } 2 c\end{array}$ \\
\hline \multicolumn{8}{|l|}{ Control variables } \\
\hline Organization: Finance & $.270^{* * *}$ & $.292^{* * *}$ & $.256^{* * *}$ & -.059 & -.078 & $.243^{* * *}$ & $.270^{* * *}$ \\
\hline Organization: Automotive & $.442^{* * *}$ & $.442^{* * *}$ & $.470^{* * *}$ & $.204^{* * *}$ & $.207^{* * *}$ & $.382^{* * *}$ & $.359^{* * *}$ \\
\hline Organization: Foodstuff & $.352^{* * *}$ & $.325^{* * *}$ & $.324^{* * *}$ & .004 & .016 & $.299^{* * *}$ & $.304^{* * *}$ \\
\hline Job grade & $-.173^{* *}$ & $-.176^{* *}$ & $-.164^{* *}$ & $-.220^{* * *}$ & $-.184^{* *}$ & -.086 & -.101 \\
\hline Age & $.136^{*}$ & $.138^{*}$ & $.137^{*}$ & -.030 & -.027 & $.178^{* *}$ & $.158^{* *}$ \\
\hline Tenure & .024 & .044 & .038 & .018 & .005 & .041 & .061 \\
\hline \multicolumn{8}{|l|}{ HCPM practices } \\
\hline Frequency of appraisal & & .013 & & $.192^{* * *}$ & & & -.039 \\
\hline Involvement in setting objectives & & .045 & & $.096^{*}$ & & & -.006 \\
\hline Personal targets set in appraisal & & .030 & & $.129^{* *}$ & & & -.016 \\
\hline Training opportunities offered in appraisal & & $.159^{* * *}$ & & $.220^{* * *}$ & & & .081 \\
\hline Choice over pay and benefits & & .073 & & .074 & & & .046 \\
\hline HCPM single variable & & & $.163^{* * *}$ & & $.389^{* * *}$ & & \\
\hline \multicolumn{8}{|l|}{ Organizational justice } \\
\hline Interactional justice in appraisal/objective setting & & & & & & $.116^{*}$ & $.132^{*}$ \\
\hline Interactional justice in reward & & & & & & .004 & .000 \\
\hline Procedural justice in performance management & & & & & & .102 & .081 \\
\hline Distributive justice in appraisal/objective setting & & & & & & $.157^{* *}$ & $.136^{* *}$ \\
\hline Distributive justice in reward & & & & & & $.096^{*}$ & $.106^{*}$ \\
\hline$\overline{\mathrm{R}^{2}}$ & .192 & .233 & .217 & .236 & .215 & .320 & .328 \\
\hline Total F & $20.119^{* * *}$ & $12.916^{* * *}$ & $18.663^{* * *}$ & $13.196^{* * *}$ & $18.581^{* * *}$ & $19.778^{* * *}$ & $13.255^{* * *}$ \\
\hline Adjusted $\mathrm{R}^{2}$ & .183 & .215 & .205 & .218 & .204 & .304 & .303 \\
\hline$\Delta \mathrm{R}^{2}$ & & .041 & .025 & .044 & .023 & .128 & .095 \\
\hline $\mathrm{N}$ & 514 & 480 & 480 & 482 & 482 & 475 & 452 \\
\hline
\end{tabular}

Note: reference organization $=$ Communications (the only public sector organization included). 
Hypothesis 1 proposes a positive relationship between HCPM as experienced by employees and levels of employee commitment. Column 2 (H1) of Table 3 shows the results of the regression analysis. One practice shows a significant relationship - training opportunities offered in appraisal. The variance explained increases by $4.1 \%$ above that explained by the control variables alone. To test this relationship further, a single HCPM practices score was calculated by summing the component parts; this new variable also shows a significant relationship with commitment (Table 3, column 3). Therefore the direct link between experienced performance management practices and employee commitment is confirmed.

Hypothesis 2 suggests (a) employee experiences of HCPM are related to their perceptions of organizational justice; (b) there is a positive direct relationship between perceived organizational justice and employee commitment; and (c) this will mediate the relationship between experienced HCPM practices and commitment levels. Firstly, the results of H2a are shown in column 4, Table 3 . In order to calculate a single organizational justice dependent variable, the mean score across the five dimensions of organizational justice was calculated. Four of the five HCPM practices are shown to have a significant relationship with perceived organizational justice, explaining $24 \%$ of variance with the control variables included. These results show that perceptions of justice of HCPM practices improve particularly the more frequently employees experience appraisal, the more involved they are in setting their own targets, and the more frequently appraisal discussions result in development opportunities and new targets being set. As above, the test was also rerun using the single HCPM variable including all five elements; this combined variable again shows a significant relationship with organizational justice (Table 3, column 5).

Secondly, looking at column $6(\mathrm{H} 2 \mathrm{~b})$ in Table 3, distributive justice in appraisal, objective setting and reward, and interactional justice in appraisal and objective setting have a significant positive effect on employee commitment. Only employee perceptions of interactional justice in reward do not affect their level of commitment to the organization.

Exploring the mediating effect of justice, column $7(\mathrm{H} 2 \mathrm{c})$ of Table 3 shows that the addition of organizational justice to the equation has increased the variance explained from $23 \%$ to $33 \%$, and the performance management practices are no longer significant at the $\mathrm{p}<.05$ level, indicating a full mediation relationship. In other words, in addition to the actual presence of HCPM practices, these practices must be perceived to be fair in order for their full effect on commitment levels to be observed.

Hypothesis 3 introduces the notion of the importance of trust in the employer/senior management as an additional contextual variable which may help explain levels of commitment. Firstly, the relationship between trust and employee commitment was explored. Based on ANOVA analyses, column 1 (H3a) of Table 4 shows that trust is very strongly and positively related to employee commitment. Secondly, to explore hypothesis $3 \mathrm{~b}$, the single summed experienced HCPM practices variable was used. When looking at the role of trust as a moderator of the HCPM practices - employee commitment relationship, Table 4, column 2 (H3b) shows the positive significant interaction effect of HCPM practices and trust in employer. Support is thus found for both hypotheses: the level of trust an employee has in the employer effects the extent to which HCPM practices are linked with higher commitment. Although the variance in organizational justice explained $\left(\mathrm{R}^{2}\right)$ increases from $47 \%$ to $53 \%$, there is a decrease in the adjusted $\mathrm{R}^{2}$ figure (from $42 \%$ to $36 \%$ ). Given that adjusted $\mathrm{R}^{2}$ corrects for the number of variables in the model, this implies the new model (H3b) is less efficient in its ability to predict organizational justice than the previous model (H3a). 
Table 4: Factorial ANOVA results

\begin{tabular}{|c|c|c|c|c|c|c|c|c|}
\hline & \multicolumn{4}{|c|}{ Employee commitment } & \multicolumn{4}{|c|}{ Organizational justice } \\
\hline & \multicolumn{2}{|c|}{ H3a } & \multicolumn{2}{|c|}{ H3b } & \multicolumn{2}{|c|}{ H4a } & \multicolumn{2}{|c|}{ H4b } \\
\hline & $F$ & $\mathrm{df}$ & $F$ & $\mathrm{df}$ & $F$ & $\mathrm{df}$ & $F$ & $\mathrm{df}$ \\
\hline Organization & $10.904^{* *}$ & 1 & $10.258^{* *}$ & 1 & $4.842^{*}$ & 1 & $3.352^{+}$ & 1 \\
\hline Job grade & 1.393 & 1 & .451 & 1 & $4.123^{*}$ & 1 & $3.578^{+}$ & 1 \\
\hline Age & $10.506^{* *}$ & 1 & $12.694^{* *}$ & 1 & 2.105 & 1 & .140 & 1 \\
\hline Tenure & .039 & 1 & .111 & 1 & .296 & 1 & .299 & 1 \\
\hline $\begin{array}{l}\text { HCPM } \\
\text { Trust in employer }\end{array}$ & $8.398^{* * *}$ & 39 & & & $6.081^{* * *}$ & 40 & & \\
\hline HCPM $x$ Trust in employer & & & $2.594^{* * *}$ & 124 & & & $2.962^{* * *}$ & 126 \\
\hline $\mathrm{R}^{2}$ & .466 & & .529 & & .385 & & .549 & \\
\hline Adjusted $\mathrm{R}^{2}$ & .417 & & .358 & & .328 & & .382 & \\
\hline $\mathrm{N}$ & 514 & & 480 & & 515 & & 482 & \\
\hline
\end{tabular}

${ }^{+} \mathrm{p}<.10, * \mathrm{p}<.05, * * \mathrm{p}<0.01, * * * \mathrm{p}<0.001$.

Hypothesis 4a explores the relationship between trust and organizational justice. Table 4, column $3(\mathrm{H} 4 \mathrm{a})$ shows that there is a positive significant relationship between trust and justice perceptions with the control variables included. Hypotheses $4 \mathrm{~b}$ then explores the moderating role of trust in the relationship between experienced HCPM practices and perceived organizational justice. Again Table 4, column 4 (H4b), shows a strong positive effect. This shows how trust in the employer plays a significant moderating role in the relationship between HCPM practices and employee perceptions of organization justice: the more trust, the higher the chance employees will consider the HCPM practices to be fair.

\section{DISCUSSION}

This paper set out to look at the relationship between employee perceptions of HCPM practices and their commitment to the organization. In addition, the study was designed to explore the mechanisms by which these perceptions influence particular employee attitudes and behaviours, and the effect of the broader organization context on how this mechanism works.

All the hypotheses received some support. There is a strong positive relationship between employee experiences of HCPM practices and perceptions of justice, and between perceived levels of justice and employee commitment, which is in line with previous studies (Folger and Konovsky, 1989; Greenberg, 1990; McFarlin and Sweeney, 1992). The link between HCPM practices and commitment is fully mediated by perceptions of organizational justice, especially distributive and interactional justice. This supports the notion of the importance of justice in explaining employee attitudes and behaviours (cf. Greenberg, 1990). Looking at the role of employee trust in the organization, this is found to moderate the relationship between HCPM and perceptions of justice, and between HCPM and levels of commitment. The theoretical argument presented by Dirks and Ferrin (2001: 463) that trust moderates the relationship between an interaction partner's action and the trustee's response has thus been tested here and found to be supported by the empirical data. 
Thus the main findings to emerge from the study are threefold. Firstly, at a theoretical level, the study contributes to the growing literature on how HRM practices and their impact as perceived by employees result in HRM outcomes ( $c f$. Guest, 1997; Purcell et al., 2003). In particular, the findings explain some of the 'black box' workings: HCPM practices achieve their aim of higher commitment provided these practices are perceived to be fair, which in turn is facilitated by high levels of trust in the organization (cf. Dirks and Ferrin, 2001). HCWPs should thus include performance management elements which allow employee involvement (cf. Gardener et al., 2001) and opportunities for development, but they also need to be built on processes and interactions that are considered fair by employees.

The second main contribution of the study is a further definition of the variables which constitute organizational justice. Based on previous research, we would expect to see the strongest relationship to be observed between procedural justice and employee commitment (cf. Folger and Konovsky, 1989; McFarlin and Sweeney, 1992). Distributive justice in contrast has previously been most likely to be related to personal satisfaction outcomes, rather than broader organization assessments such as commitment (cf. McFarlin and Sweeney, 1992). The study however shows that perceptions of the distributive justice of HCPM practices have the strongest impact on employee commitment. This may be specific to the organizations selected, as they were all undergoing major change programmes. Further research is required in this area to uncover whether in times of change, or other significant organizational events, distributive justice takes on a different priority for employees. Indeed, it is acknowledged that little is known about the differential effects of various aspects of organizational change on different aspects of the attitudes of those individuals affected by the change, such as levels of commitment (Fedor et al., 2006).

The significant effect of organization observed in the results may also indicate that the findings are specific to a particular context. To explore this further, the research models were tested in each of the four separate company datasets (see Appendix). The results indicate that the factors are reliable in all four cases, with Hypotheses 2a, 2b, 2c, 3a and 4a all fully supported in each individual organization. Hypothesis $4 \mathrm{~b}$, suggesting the moderating role of trust between HCPM and justice, found support in three organizations. Hypothesis 1, suggesting a direct link between experienced HCPM practices and employee commitment, and hypothesis $3 \mathrm{~b}$, suggesting the moderating role of trust between HCPM and commitment, were supported in two organizations. In general, these results support the generalisability of the findings, although further research would be needed in multiple settings to test this further.

Finally, in continuing the discussion as to whether the three dimensions of organizational justice identified - procedural, distributive, interactional - do indeed exist as separate dimensions in the perceptions of employees (cf. Cropanzano et al., 2002; Greenberg, 1990), this study has shown that separate factors did emerge in most of these dimensions. Only in the area of reward did employee opinions on procedural and interactional justice items overlap. In all other dimensions, distributive, interactional and procedural justice items created separate factors. 


\section{CONCLUSIONS}

In our exploration of the 'black box' debate on the link between HRM and performance, we have seen how creating a set of practices for high commitment performance management that engender feelings of perceived justice amongst employees leads to increased levels of employee commitment, moderated by employee levels of trust in the employer.

For organizations, this study emphasizes the importance of justice and trust to achieve desired performance outcomes. As Folger and Konovsky (1989: 128) conclude: "to be maximally effective in sustaining employee commitment to an organization and trust in its management, those making allocative decisions [...] must take procedural justice into account". Our findings refine this statement to emphasize the moderating role of trust in achieving employee commitment and perceptions of justice, as well as emphasizing the importance of three different types of justice. The key is thus to find ways of triggering discretionary behaviour in employees and management in order to stimulate organizational commitment ( $c f$. Purcell et $a l .$, 2003). Particularly for the organizations involved in this study, our findings suggest that increased focus on improving perceptions of justice, through ensuring line management are capable of carrying out HCPM practices, may help improve commitment to the organization during change.

Despite the interesting findings emerging from this study, it is important to note that the research is based on self-report data on levels of commitment: future studies could try to measure this also from a line management perspective, for example, to help minimize possible problems of common-method variance. In addition, we proposed a causal model for the linkage between organizational justice and employee commitment and the role of trust, and although the findings from our cross-sectional study were consistent with the mediating and moderating models proposed, alternative causal paths may be possible. A full exploration of the causal links requires a longitudinal study.

The study presented here leads us to believe that it is essential to observe the actual employee experience of HCPM practices and outcomes at employee level if we are to understand their effects on firm performance. 


\section{Appendix: Single company comparative results}

\begin{tabular}{|c|c|c|c|c|c|}
\hline & Finance & Automotive & Food & Communication & Full dataset \\
\hline \multicolumn{6}{|l|}{ Reliability (Cronbach $\alpha$ ) } \\
\hline Interactional justice in appraisal and objective setting & .935 & .927 & .914 & .925 & .928 \\
\hline Interactional justice in reward & .929 & .930 & .894 & .904 & .926 \\
\hline Procedural justice in performance management & .906 & .910 & .886 & .925 & .909 \\
\hline Distributive justice in appraisal and objective setting & .897 & .893 & .878 & .865 & .888 \\
\hline Distributive justice in reward & .838 & .862 & .822 & .812 & .836 \\
\hline Trust in employer & .876 & .862 & .858 & .927 & .899 \\
\hline Commitment & .832 & .797 & .753 & .784 & .830 \\
\hline \multicolumn{6}{|l|}{ Regression (standardized $\beta$ ) } \\
\hline \multicolumn{6}{|l|}{$H 1$ (commitment) } \\
\hline HCPM & .099 & $.363^{* *}$ & $.191^{+}$ & .113 & $.163^{* * *}$ \\
\hline \multicolumn{6}{|l|}{$H 2 a$ (justice) } \\
\hline HCPM & $.368^{* * *}$ & $.392^{* *}$ & $.580^{* * *}$ & $.249^{*}$ & $.389^{* * *}$ \\
\hline \multicolumn{6}{|l|}{$H 2 b$ (commitment) } \\
\hline Justice & $.332^{* * *}$ & $.336^{* *}$ & $.472^{* * *}$ & $.429^{* * *}$ & $.359^{* * *}$ \\
\hline \multicolumn{6}{|l|}{$H 2 c$ (commitment) } \\
\hline HCPM & .024 & .147 & .063 & .126 & .082 \\
\hline Justice & $.328^{* * *}$ & $.266^{*}$ & $.461^{* * *}$ & $.453^{* * *}$ & $.354^{* * *}$ \\
\hline \multicolumn{6}{|l|}{ ANOVA (F values) } \\
\hline$H 3 a$ (commitment) & $3.931^{* * * *}$ & $3.996^{* * *}$ & $2.353^{* *}$ & $4.407^{* * *}$ & $8.398^{* * *}$ \\
\hline$H 3 b$ (commitment) & $2.353^{* * *}$ & 1.494 & $1.642^{+}$ & $2.124^{* *}$ & $2.594^{* * *}$ \\
\hline$H 4 a$ (justice) & $3.451^{* * *}$ & $2.945^{* *}$ & $3.354^{* * *}$ & $3.876^{* * *}$ & $6.081^{* * *}$ \\
\hline$H 4 b$ (justice) & $2.256^{* * *}$ & $4.400^{* * *}$ & $1.564^{+}$ & $3.046^{* * *}$ & $2.962^{* * *}$ \\
\hline
\end{tabular}

${ }^{+} \mathrm{p}<.10, * \mathrm{p}<.05, * * \mathrm{p}<0.01, * * * \mathrm{p}<0.001$. 


\section{REFERENCES}

Arthur, J. (1994), "Effects of human resource systems on manufacturing performance and turnover", Academy of Management Journal, Vol. 37 No. 3, pp. 670-687.

Aryee, S., Budhwar, P. S. and Chen, Z. X. (2002), "Trust as a mediator of the relationship between organizational justice and work outcomes: test of a social exchange model", Journal of Organizational Behavior, Vol. 23, pp. 267-285.

Bies, R. J., and Moag, J. S. (1986), "Interactional justice”, in Bies, R. J. (Ed.), Research on Negotiation in Organizations, Vol. 1, JAI Press, Greenwich, CT, 43-55.

Blau, P. M. (1964), Exchange and power in social life, Wiley, New York.

Boxall, P., and Macky, K. (2009), "Research and theory on high-performance work systems: progressing the high-involvement stream", Human Resource Management Journal, Vol. 19 No. 1, pp. 1-21.

Chang, E. (2005), "Employees' overall perception of HRM effectiveness", Human Relations, Vol. 58 No. 4, pp. 523-544.

Cook, J. and Wall, T. (1980), "New work attitude measures of trust, organizational commitment and personal need non-fulfillment", Journal of Occupational Psychology, Vol. 53, pp. 39-52.

Costigan, R., Ilter, S. and Berman, J. (1998). "A multi-dimensional study of trust in organizations”, Journal of Managerial Issues, Vol. 10, pp. 303-317.

Cropanzano, R., Prehar, C. A. and Chen, P. Y. (2002), "Using social exchange theory to distinguish procedural from interactional justice", Group and Organization Management, Vol. 27 No.3, pp. 324-351.

Den Hartog, D.N., Boselie, P., and Paauwe, J. (2004). "Performance Management: a research agenda", Applied Psychology: an International Review, Vol. 53 No. 4, pp. 556 - 569.

Dirks, K. T. and Ferrin, D. L. (2001), "The role of trust in organizational settings", Organization Science, Vol. 12 No. 4, pp. 450-467.

Fedor, D. B., Caldwell, S. and Herold, D. M. (2006), "The effects of organizational changes on employee commitment: a multilevel investigation", Personnel Psychology, Vol. 59, pp. $1-29$.

Fletcher, C. and Williams, R. (1996), "Performance management, job satisfaction and organizational commitment", British Journal of Management, Vol. 7, pp. 169-79.

Folger, R. and Konovsky, M. A. (1989), "Effects of procedural and distributive justice on reactions to pay raise decisions", Academy of Management Journal, Vol. 32 No. 11, pp. 115-130.

Gabarro, J. J., and Athos, J. (1976), Interpersonal Relations and Communications, Prentice Hall, New York.

Gardner, T. M., Moynihan, L. M., Park, H. J. and Wright, P. M. (2001), “Beginning to unlock the black box in the HR firm performance relationship: the impact of HR practices on employee attitudes and employee outcomes", working paper 01-12, CAHRS, Cornell University, USA.

Gould-Wiliams, J. (2004), “The effects of 'high commitment' HRM practices on employee attitude: the views of public sector workers, Public Administration, Vol. 82 No. 1, pp. 63 81.

Gratton, L. and Truss, C. (2003), “Three dimensional people strategy: putting human resource policies into action", Academy of Management Executive, Vol. 17 No. 3, pp. 74-86.

Greenberg, J. (1990), “Organizational justice: yesterday, today, and tomorrow”, Journal of Management, Vol. 16 No. 2, pp. 399-432.

Guest, D. E. (1987), "Human resource management and industrial relations", Journal of Management Studies, Vol. 24 No. 5, pp. 503-521. 
Guest, D. E. (1997), "Human resource management and performance: a review and research agenda", International Journal of Human Resource Management, Vol. 8 No. 3, pp. 263276.

Guest, D. (1999), “HRM: the workers' verdict”, Human resource Management Journal, Vol. 9, pp. 5-25.

Guest, D. E., Michie, J., Conway, N. and Sheehan, M. (2003), "Human resource management and corporate performance in the UK", British Journal of Industrial Relations, Vol. 41 No.2, pp. 291-314.

McAllister, D. J. (1995), “Affect- and cognition-based trust as foundations for interpersonal cooperation in organizations", Academy of Management Journal, Vol. 38 No. 1, pp. 2429.

McFarlin, D. B. and Sweeney, P. D. (1992), "Distributive and procedural justice as predictors of satisfaction with personal and organizational outcomes", Academy of Management Journal, Vol. 35 No. 3, pp. 626-637.

Macky, K. and Boxall, P. (2007), "The relationship between 'high-performance work practices' and employee attitudes: an investigation of additive and interaction effects", International Journal of Human Resource Management, Vol. 18 No. 4, pp. 537.

Mathieu, J. E. and Zajac, D. M. (1990), "A review and meta-analysis of the antecedents, correlates, and consequences of organizational commitment", Psychological Bulletin, Vol. 108 No. 2, pp. 171-194.

Mowday, R., Steers, R. and Porter, L. (1979), "The measurement of organizational commitment”, Journal of Vocational Behaviour, Vol. 14, pp. 224 - 247.

Organ, D. (1990), "The motivational basis of organizational citizenship behavior", in Cummings, L. L. and Staw, B. M. (Eds.), Research in organizational behavior, Vol. 12 , JAI Press, Greenwich, CT, pp. 43-72.

Paauwe, J. and Farndale, E. (2005), "International HRM and performance", in Björkman, I. and Stahl, G. (Eds.), Handbook of International Human Resource Management Research, Edward Elgar Publishing, UK, pp. 91-111.

Podsakoff, P. M. and Organ, D. W. (1986), "Self-reports in organization research: problems and prospects", Journal of Management, Vol. 12 No. 4, pp. 531-545.

Price, J. L. and Mueller, C. W. (1986), Handbook of organizational measurement, Pitman Marshfield, MA.

Purcell, J., Kinnie, N. J., Hutchinson, S., Rayton, B. and Swart, J. (2003), Understanding the people and performance link: unlocking the black box, CIPD, London.

Rousseau, D. S., Sitkin, S., Burt, R. and Camerer, C. (1998), "Not so different after all: a cross-discipline view of trust", Academy of Management Review, Vol. 23 No. 3, pp. 387392.

Skarlicki, D., Folger, R. and Tesluk, P. (1999), Academy of Management Journal, Vol. 42 No. 1, pp. $100-108$.

Whitener, E. (2001), "Do "high commitment" human resource practices affect employee commitment? A cross-level analysis using hierarchical linear modeling", Journal of Management, Vol. 27 No. 5, pp. 515 - 535.

Wood, S. (1999), "Human resource management and performance", International Journal of Management Review, Vol. 1 No. 4, pp. 367-413.

Wood, S. and de Menezes, L. (1998), "High commitment management in the UK: Evidence from the Workplace Industrial Relations Survey and Employers' Manpower and Skills Practices Survey", Human Relations, Vol. 51, pp. 485-517.

Wright, P. and Nishii, L. H. (2004), Strategic HRM and organizational behavior: integrating multiple levels of analysis. Paper presented at the international seminar 'HRM: What's Next?', Erasmus University Rotterdam, The Netherlands. 